\title{
BRANŻOWE JEDNOSTKI WZROSTU W GENEROWANIU NIERÓWNOŚCI MIĘDZY PAŃSTWAMI UNII EUROPEJSKIEJ
}

\begin{abstract}
Streszczenie
W opracowaniu analizom poddano skalę nierównomierności wytwórczych pomiędzy państwami członkowskimi Unii Europejskiej. Badane dysproporcje w poziomie wartości dodanej brutto na mieszkańca odzwierciedliły zarówno poziom efektywności produkcyjnej, jak i poziom dobrobytu wypracowywanego w danej gospodarce. Tym samym stanowily podstawę do oceny wewnątrzunijnej spójności społeczno-ekonomicznej i przebiegu procesów konwergencyjnych.

Oszacowania poziomu zróżnicowania rozkładu produkcji w ujęciu międzynarodowym zaprezentowano przede wszystkim na podstawie kształtowania się współczynnika Giniego. Prowadzone analizy pozwoliły na ocenę przebiegu procesów integracyjnych w Unii Europejskiej w okresie 2004-2013. Zmiany poziomu wspó1czynnika Giniego wskazały na zmniejszanie się nierównomierności wytwórczych po 2004 roku, jednak zarazem na załamanie się tendencji konwergencyjnych w okresie kryzysowym.

W artykule przedmiotem szczególnego zainteresowania stała się kwestia nierównomierności wytwórczych w poszczególnych branżach. Przedstawione analizy umożliwily identyfikację tych dziedzin gospodarczych, które charakteryzują się najwyższymi dysparytetami międzynarodowymi, jak i tych, w których zróżnicowania wytwórcze sa najmniejsze. Do pierwszej z tych grup zaliczono finanse, usługi profesjonalne i informacyjne, natomiast do drugiej rolnictwo, przemysł i tradycyjne usługi.

Ponadto, w artykule pozytywnie zweryfikowano tezę badawczą o występowaniu największych nierównomierności wytwórczych w ramach najbardziej dynamicznie rozwijających się branż o cechach biegunów wzrostu. Dostrzeżono dość silne związki między dynamika przyrostu wartości dodanej brutto per capita a skalą dysproporcji wytwórczych mierzonych współczynnikiem Giniego w poszczególnych branżach. Procesy rozwojowe w Unii Europejskiej przyjmuja więc charakter polaryzacyjno-dyfuzyjny. Ich spójny przebieg wymaga zapewnienia warunków absorpcji nowoczesnych rozwiązań w krajach odrabiających dysproporcje rozwojowe.
\end{abstract}

Słowa kluczowe: branże, jednostki wzrostu, nierówności wytwórcze, konwergencja

\section{BRANCH GROWTH POLES AND GENERATING INEQUALITY BETWEEN EU COUNTRIES}

\section{Summary}

The analysis presented in the study concerns the scale of productive inequality between EU member states. Disparities in the level of gross value added per capita reflect both the level of productive efficiency and the level of welfare produced by an economy. They could constitute a basis for an assessment of socio-economic cohesion in the EU and convergence processes. 
Estimations of the level of differences in international distribution of production are based mainly on the Gini coefficient. The analyses allow the author to assess integration processes in the EU in the years 2004-2013. Changes in the level of the Gini coefficient indicate that productive inequality has decreased since 2004. However, they indicate a breakdown in convergence tendencies during the crisis.

Special attention is paid to productive inequality in particular branches. Presented analyses make it possible to identify the economic branches that are characterized by the highest international disparities, as well as those in which productive differences are the lowest. The former group comprises: finances, professional services, and information, while the latter: agriculture, industry, and traditional services.

Additionally, a research thesis that the highest productive inequality exists in the most dynamically developing branches with the features of growth poles is positively verified. Quite strong relations can be observed between the growth dynamics of gross value added per capita and the scale of production disparities measured by the Gini coefficient in the studied branches. Developmental processes in the EU assume, therefore, a polarizing and diffusive character. To achieve consistent development, it is necessary to promote conditions for absorption of modern solutions in catching-up countries.

Key words: branches, growth poles, productive inequality, convergence

JEL: JEL: E01, E23, L16, O11, O14

\section{Wstęp}

Wyzwania rozwoju społeczno-gospodarczego wyzwalają dążenia do zapewnienia jak najwyższego poziomu życia jak najszerszym grupom społecznym. Tym samym zawierają w sobie imperatyw harmonizowania procesów wzrostowych i spójności społecznej. Jest to szczególnie istotne w sytuacji, kiedy procesy konwergencji przeciętnego poziomu rozwoju łączą się z narastaniem zróżnicowań dochodowych w skali globalnej [Kołodko, 2014, s. 26; Kołodko, 2008, s. 151], a jednocześnie dysproporcje międzynarodowe pozostają wielokrotnie wyższe niż te obserwowane w ramach poszczególnych państw [Piketty, 2015, s. 28].

Cele wzrostu i spójności stanowią zasadniczą przesłankę dla europejskich idei integracyjnych. Warunkują one konieczność takiego kształtowania polityki społeczno-gospodarczej, która umożliwiłaby osiagnięcie faktycznej spójności międzynarodowej, tak w wymiarze poziomu wytwarzanej produkcji, jak i jej dystrybucji. Wymaga się więc by polityka taka koncentrowała się zarówno na stymulowaniu procesów wzrostu gospodarczego, ze szczególną uwaga zwróconą na kraje konwergujące, jak i minimalizowaniu szeroko rozumianych nierówności, w tym tych dostrzeganych w układach przestrzennych.

Priorytetyzacja celów rozwojowych prowadzi do przyjęcia jednego z dwóch podejść do kształtowania polityki społeczno-gospodarczej [OECD, 2015, s. 37]. Pierwsze z nich zakłada wybór rozwiązań sprzyjających osiaganiu wysokiego poziomu produkcji i ocenę ich wpływu na poziom nierówności społecznych. W drugim poszukuje się rozwiązań optymalnych pod względem minimalizowania nierówności społecznych i następnie uwzględnia ich efekty wzrostowe. Podejścia te pozostaja w wysokim stopniu kompatybilne, choć mogą przyczynić się do wyboru odmiennych rozwiązań praktycznych.

Priorytetyzacja celów rozwojowych nie pozostaje bez wpływu na zalecenia w zakresie kształtowania polityki sektorowo-branżowej. Z jednej bowiem strony stymulowanie konkurencyjności oznacza nieodzowność identyfikacji sektorów najbardziej innowacyjnych, 
o wysokiej dynamice wytwarzania, które są określane jako tzw. jednostki motoryczne czy bieguny wzrostu. Z drugiej strony zapewnianie spójności warunkuje wsparcie dla rozwoju sektorów gwarantujących możliwości szerokiej inkluzji na etapie uczestnictwa w kreacji i jej efektach. Jednocześnie z racji harmonizowania procesów wzrostowych i spójnościowych optymalne jest dynamizowanie takich jednostek motorycznych, które generuja pozytywne efekty dyfuzyjne, zapewniajac udział szerokim grupom społecznym w wynikach gospodarczych.

Wskazanie sektorów, które pozwoliłyby na harmonizowanie celów wzrostowych i spójnościowych, wymaga oceny ich charakterystyk w obu tych wymiarach. Ostateczny wybór branż, na których dynamizacji byłyby skoncentrowane instrumenty polityki sektorowej, zawsze jest przy tym decyzją subiektywna, opartą na złożonych kryteriach wyboru i ich priorytetyzacji.

Rola poszczególnych sektorów w procesach rozwojowych stanowiła przedmiot ożywionej dyskusji w połowie XX wieku, kiedy W.A. Lewis przedstawił teorię industrializacji, rozwiniętą następnie przez J. Fei i G. Ranisa oraz D.W. Jorgensona. Były to modele gospodarki dualnej, w których mechanizm rozwoju zakładał stopniową redukcję sektora tradycyjnego. W tym kontekście trwały debaty między zwolennikami wzrostu zrównoważonego (R. Nurkse, P. Rosenstein-Rodan) a niezrównoważonego (A.O. Hirschman, P. Streeten), pojawiały się koncepcje polaryzacji sektorowej i przestrzennej oraz trwały poszukiwania sektorów prowadzacych w procesie fazowego rozwoju (W.W. Rostow, J.A. Schumpeter, F. Perroux, G. Myrdal, A.O. Hirschman) [Kozak, 2001, s. 109-162; von Stackelberg, Hahne, 1998, s. 19-110]. Wcześniejsze koncepcje, uwzględniające trójsektorowe zmiany w procesie rozwoju, zostały przedstawione przez: C. Clarka, A.G. Fishera i J. Fourastiégo. Na podstawie analiz sektorowych sformułowano także strukturalną hipotezę konwergencji, która wywołała szeroką dyskusję [Klodt, 1995, s. 285-301]. Podejmowano również próby empirycznej oceny wpływu zmian sektorowych na przebieg procesów konwergencji w Unii Europejskiej [Sassi, 2011, s. 101-115]. Prowadzone w różnorodnych aspektach badania nad charakterem sektorów w rozwoju społeczno-gospodarczym ukazuja zmienność optymalnych relacji strukturalnych i roli poszczególnych branż w tym procesie. Tym samym dowodzą aktualności analiz sektorowo-branżowych uwarunkowań osiagania spójności w Unii Europejskiej, stanowiących podstawę formułowania zaleceń pod adresem polityki społeczno-gospodarczej.

W powyższym kontekście w opracowaniu dokonano identyfikacji branż, w których międzynarodowe dysproporcje w rozkładzie wytwarzania sa najmniejsze i w ten sposób ich rozwój przyczynia się do minimalizowania rozbieżności między państwami członkowskimi Unii Europejskiej, jak również tych branż, które cechują się największymi nierównościami i w efekcie ograniczają konwergencję wewnątrzwspólnotową. Podjęto więc próbę określenia pożądanych kierunków modernizacji sektorowo-branżowej zakładającej dążenie do spójności, rozumianej jako minimalizacja zróżnicowań w zakresie przeciętnego poziomu wytwarzania i dochodów między 28 krajami Unii Europejskiej.

W opracowaniu poszukiwano także odpowiedzi na pytanie o dynamikę rozwoju branż, które wyróżniają się największymi i najmniejszymi nierównościami. Zweryfikowano tezę o największej skali zróżnicowań w branżach, które przyjmują charakter motorycznych jednostek wzrostu, a więc cechują się najwyższą dynamiką wytwarzania. Potwierdzenie 
tej tezy wskazywałoby na biegunowy charakter procesów rozwojowych w Unii Europejskiej, które moga prowadzić do wzrostu polaryzacji. W takiej sytuacji warunkiem uniknięcia dywergencji byłoby uruchomienie efektów dyfuzyjnych w przestrzeni międzynarodowej. Negacja wstępnej tezy sugerowałaby natomiast prokonwergencyjny charakter modernizacji strukturalnej. Wymogiem zwiększania spójności wewnątrzwspólnotowej byłoby wówczas wspieranie procesów unowocześniania i pokonywania barier strukturalnych.

Realizacja tych celów bazuje na analizach danych zaczerpniętych z bazy statystycznej Eurostatu dla okresu 2004-2013 [National Accounts..., Population...]. Pozwoliły one na oszacowanie w ujęciu branżowym wartości współczynnika Giniego, wykorzystanego do oceny nierównomierności rozkładu wytwarzania wartości dodanej brutto na mieszkańca pomiędzy 28 państwami Unii Europejskiej. Obliczenia wartości współczynnika Giniego dokonano na podstawie wzoru:

$$
I_{\text {Gini }}(x)=\frac{1}{2 N^{2} * W_{A}(x)} \sum_{n=1}^{N} \sum_{n^{\prime}=1}^{N}\left|x_{n}-x_{n^{\prime}}\right|
$$

gdzie: $\mathrm{x}_{\mathrm{n}}$ - wartość zmiennej dla obiektu $\mathrm{n}, \mathrm{n}=1, \ldots, \mathrm{N}, \mathrm{W}_{\mathrm{A}}(\mathrm{x})$ - średnia wartość $\mathrm{x}$ dla N obiektów [por. Foster, Seth, Lokshin, Sajaia, 2013, s. 94; Jabkowski, 2009, s. 26-41]. Analizowaną zmienną była wartość dodana brutto na mieszkańca ogółem oraz wytworzona w poszczególnych branżach w każdym z N=28 państw Unii Europejskiej. Tym samym materiał badawczy stanowiło 308 obserwacji zmiennej (wartość ogółem i 10 branży w 28 krajach) w każdym z analizowanych lat (łącznie 3080 obserwacji).

Przy tym analizowane branże zostały określone zgodnie $z$ agregacją Eurostatu jako:

- A: Rolnictwo, leśnictwo, rybołówstwo;

- B-E: Przemysł;

- F: Budownictwo;

- $\quad$ G-I: Handel, transport, zakwaterowanie i gastronomia;

- J: Informacja i komunikacja;

- K: Finanse i ubezpieczenia;

- L: Obsługa nieruchomości;

- M-N: Usługi profesjonalne, naukowe i techniczne, administracyjne i wspierające;

- O-Q: Administracja publiczna, obrona narodowa, edukacja, ochrona zdrowia i opieka społeczna;

- $\quad$ R-U: Sztuka, rozrywka, rekreacja, usługi pozostałe, działalność gospodarstw domowych oraz organizacji międzynarodowych.

Opracowanie rozpoczęto diagnozą skali nierównomierności wytwórczych w UE-28 i ich zmian w latach 2004-2013. Kolejno zaprezentowano wyniki oceny dysproporcji wytwórczych w ramach agregatów branżowych. Następnie skalę zróżnicowań w ramach poszczególnych branż zestawiono z dynamiką rozwoju tych agregatów. Artykuł zakończono konkluzjami zawierającymi wskazówki aplikacyjne w odniesieniu do kształtowania polityki strukturalnej (przemysłowej). 


\section{Nierówności wytwórcze w Unii Europejskiej}

Dysproporcje w poziomie rozwoju gospodarczego i dobrobytu społecznego w układzie międzynarodowym najczęściej są przedstawiane za pomoca porównania przeciętnego poziomu produkcji lub dochodu na mieszkańca. Miarą powszechnie akceptowana, choć niepozbawioną ograniczeń, jest wartość dodana brutto na mieszkańca. Wyniki poszczególnych gospodarek UE-28 w tym ujęciu zaprezentowano na rysunku 1.

RYSUNEK 1.

\section{Wartość dodana brutto per capita w UE-28 w 2013 roku}

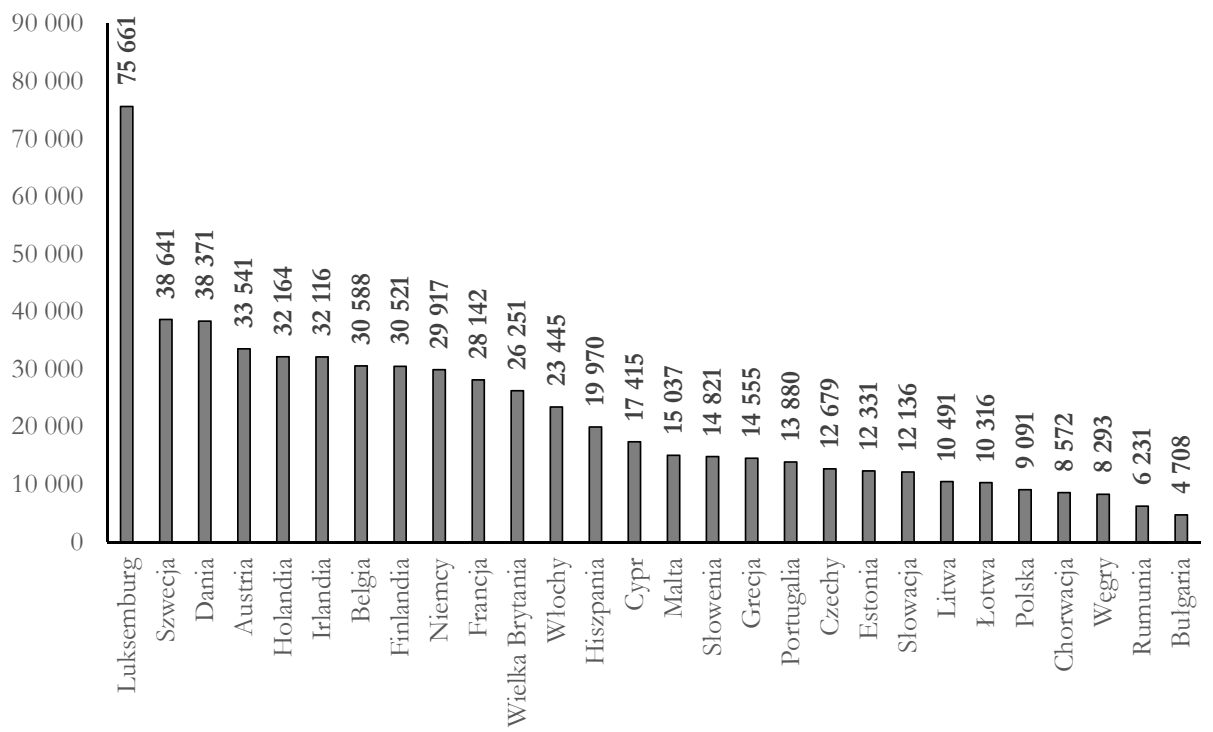

Źródło: opracowanie własne na podstawie danych Eurostat: [National Accountings...; Population...].

Najwyższą wartość dodaną brutto per capita w 2013 roku wytworzono w Luksemburgu, który wyraźnie wyróżniał się na tle ugrupowania, osiagając wyniki na poziomie 3,5-krotności wartości średniej dla 28 państw członkowskich (wynoszącej 21782 euro). Korzystne efekty produkcyjne cechowały także Szwecję i Danię, w których stanowiły około 1,8 średniej. Najniższy poziom wartości dodanej na mieszkańca zanotowano w Bułgarii, w której znalazł się on na poziomie niecałych 22\% średniej oraz Rumunii - niecałych $29 \%$ średniej. O dysproporcjach wewnątrzunijnych świadczy fakt, że wyniki wytwórcze w najuboższej Bułgarii stanowiły zaledwie $6 \%$ rezultatów działalności gospodarczej w, znajdującym się na początku zestawienia, Luksemburgu. Ponadto, współczynnik zmienności dla wyników 28 państw wynosił około $67 \%$.

Syntetyczne ujęcie nierównomierności jest również możliwe do przedstawienia na podstawie współczynnika Giniego. Taką ocenę rozkładu wytwarzania dla ogółu branż w 28 państwach członkowskich Unii Europejskiej w okresie 2004-2013 zaprezentowano na rysunku 2. Porównywaną zmienną była wartość dodana brutto na mieszkańca ogółem, a więc w ujęciu wszystkich sekcji NACE (A-U) w poszczególnych N=28 krajach. 
RYSUNEK 2.

Wartości współczynnika Giniego dla rozkładu wartości dodanej brutto per capita oraz jego liniowa i wielomianowa funkcja trendu* w UE-28, w latach 2004-2013

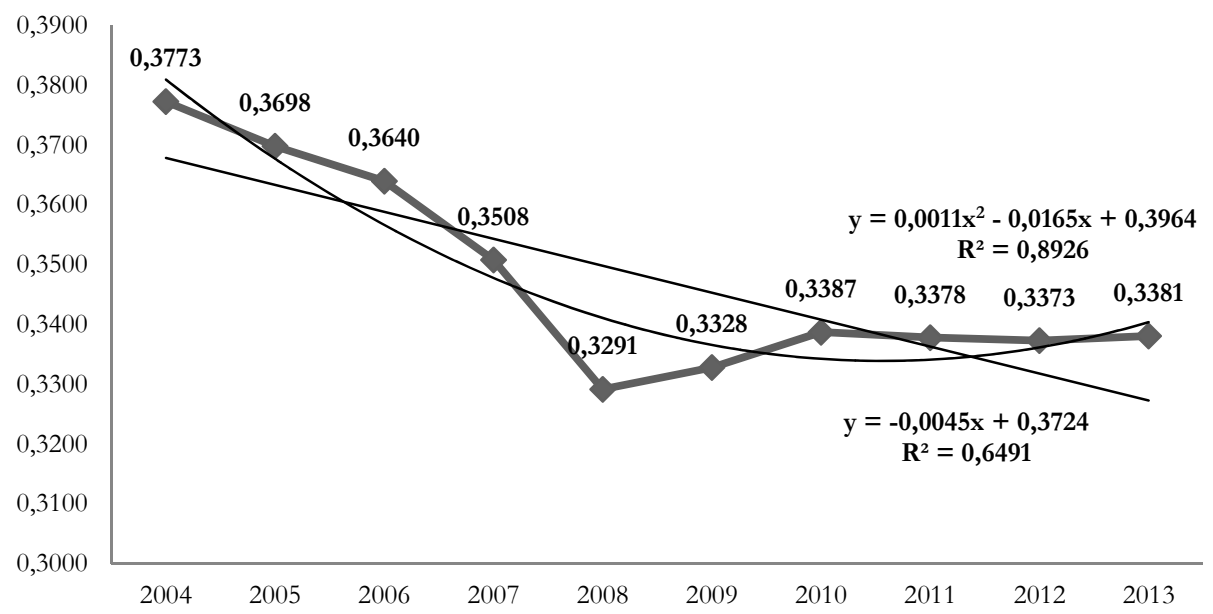

* Potęgowe, logarytmiczne i wykładnicze linie trendu charakteryzowały się niższym współczynnikiem determinacji niż wielomian kwadratowy.

Źródło: opracowanie własne na podstawie danych Eurostat: [National Accountings...; Population...].

Międzynarodowe nierówności w rozkładzie wartości dodanej brutto na mieszkańca wytwarzanej w 28 obecnych państwach członkowskich Unii Europejskiej zmniejszyły się w latach 2004-2013. Świadczy to o pogłębianiu się konwergencji między analizowanymi gospodarkami, potwierdzającej realną integrację gospodarczą. Poziom dysproporcji wytwarzania, w ujęciu ogółem mierzonym współczynnikiem Giniego, zmniejszył się z poziomu 0,38 do 0,34 . W ujęciu liniowym średnioroczne tempo zmiany tego wskaźnika wyniosło -0,0045, przy zgodności wartości zaobserwowanych w poszczególnych latach z przebiegiem tendencji rozwojowej określonej współczynnikiem determinacji $\mathrm{R}^{2}$ na poziomie $64,91 \%$ i istotną (dla $\left.\alpha=0,05\right)$ statystyką $F=14,8$. Zakłócenia trendu liniowego wiążą się z okresem kryzysu gospodarczego, który przyczynił się do wzrostu międzynarodowego zróżnicowania wartości dodanej brutto w roku 2009 i 2010. Dodatkowo rok 2013, który również cechował się niekorzystnymi zjawiskami koniunkturalnymi, łączył się ze wzrostem nierówności rozkładu wytwarzania. W pozostałych latach odnotowano obniżanie się dysproporcji w wartości dodanej brutto na mieszkańca w UE-28, które były szczególnie dynamiczne aż do okresu ujawnienia się kryzysu. Odwrócenie tendencji w kształtowaniu się nierównomierności wytwórczych w okresie kryzysu potwierdza oszacowany trend wielomianowy. Cechuje się on lepszym dopasowaniem do danych empirycznych niż ujęcie liniowe ( $\mathrm{R}^{2}$ na poziomie $89,26 \%$ ), a wartość parametru dowodzi początkowego spadku, a następnie wzrostu zróżnicowań. Można uznać, że nierówności w rozkładzie wartości dodanej brutto w UE-28 miały charak- 
ter procykliczny, wzrastając w okresie dekoniunktury. Świadczy to o korzystnych relacjach, które miały miejsce między wzrostem gospodarczym a nierównościami w obszarze wytwarzania. Oznacza to funkcjonowanie gospodarek Unii Europejskiej na opadającym odcinku krzywej Kuznetsa o kształcie odwróconej litery U, co jest typowe dla zaawansowanych etapów rozwoju gospodarczego.

\section{Międzypaństwowe zróżnicowania wytwarzania w układzie branżowym}

Analizy skali i przyczyn dysproporcji wytwórczych obserwowanych między państwami członkowskimi Unii Europejskiej zwracają uwagę na strukturę produkcyjną i nierównomierności występujące w poszczególnych agregatach branżowych. Poziom tych dysparytetów, mierzonych współczynnikiem Giniego w poszczególnych branżach, a także ich zmiany w czasie zaprezentowano w tabeli 1 . W przypadku każdej z branży posłużono się tu zmienną w postaci wartości dodanej brutto na mieszkańca, porównywaną między $\mathrm{N}=28$ krajami.

Uwzględniając rozkład wartości dodanej brutto w krajach UE-28 w wymiarze branżowym, można zauważyć, że najbardziej dynamicznie zmniejszały się nierówności $\mathrm{w}$ przemyśle, natomiast tendencja ta była w największym stopniu ukierunkowana. Znaczne ograniczenie zróżnicowań międzynarodowych odnotowano także w: rolnictwie, usługach profesjonalnych (M-N) oraz budownictwie, a skala ich ograniczania była zbliżona do tendencji dla wartości dodanej ogółem. Jednak w budownictwie ogólna tendencja spadkowa wartości współczynnika Giniego łączyła się z okresem zmniejszania dysproporcji w latach 2004-2008 i okresem ich wzrostu trwającym od 2009 roku. Świadczy to o zdecydowanie lepszym dopasowaniu wielomianowej funkcji trendu. Wyraźne tendencje spadkowe miały jednocześnie miejsce w obsłudze nieruchomości (L). Należy podkreślić, że we wszystkich 10 branżach zaobserwowano tendencje do zmniejszania się nierówności międzynarodowych w wytwarzanej wartości dodanej brutto na mieszkańca. Niskie współczynniki dopasowania danych empirycznych do trendu liniowego w większości przypadków wynikały ze zmiany w kształtowaniu się tendencji spadowych po 2008 roku. Zjawiska kryzysowe w Unii Europejskiej wiązały się ze wzrostem dysproporcji międzynarodowych w ujęciu większości z branży (z wyjątkiem przemysłu), choć różna była skala i szybkość tej reakcji. Takie zaburzenia znalazły potwierdzenie w wyższych wartościach współczynnika determinacji trendu wielomianowego oraz dodatniej wartości parametru tych funkcji. W szczególności korekta trendu, uwzględniająca zjawiska kryzysowe, była zasadna dla: usług społecznych, budownictwa, usług rekreacyjnych, informacji i komunikacji, handlu i gastronomii, obsługi nieruchomości, jak również usług profesjonalnych. Tym samym branże te wykazały najsilniejsze reakcje na kryzys w kontekście poziomu zróżnicowania wytwarzania między państwami Unii Europejskiej. 
TABELA 1.

Wartości współczynnika Giniego oraz parametry jego liniowej i wielomianowej* funkcji trendu w układzie branżowym w UE-28, w latach 2004-2013

\begin{tabular}{|c|c|c|c|c|c|c|c|c|c|c|}
\hline \multirow[b]{2}{*}{ Rok } & \multicolumn{10}{|c|}{ Wartości współczynnika Giniego w branżach } \\
\hline & $\mathbf{A}$ & B-E & F & G-I & $\mathbf{J}$ & K & $\mathbf{L}$ & M-N & O-Q & R-U \\
\hline 2004 & 0,2425 & 0,3584 & 0,4011 & 0,3352 & 0,4261 & 0,5931 & 0,4114 & 0,4533 & 0,4003 & 0,3714 \\
\hline 2005 & 0,237 & 0,3442 & 0,3915 & 0,3236 & 0,4177 & 0,6065 & 0,4014 & 4401 & 0,3906 & 3512 \\
\hline 2006 & 0,2062 & 0,3368 & 0,3734 & 0,3113 & 0,4071 & 0,6192 & 3941 & 4352 & 0,3864 & 0,3391 \\
\hline 2007 & 0,2102 & 0,3285 & 0,3429 & 0,2987 & 0,4043 & 0,6043 & 3817 & 4267 & 0,3756 & 0,325 \\
\hline 2008 & 0,1971 & 0,3066 & 0,3035 & 0,2836 & 0,385 & 0,5762 & 0,3725 & 0,4106 & 0,3609 & 0,3283 \\
\hline 2009 & 0,2208 & 0,3017 & 0,3224 & 0,2886 & 0,3796 & 0,5731 & 0,3822 & 0,4103 & 0,3661 & 0,3348 \\
\hline 2010 & 0,2176 & 0,2991 & 0,3355 & 0,3003 & 0,3991 & 0,5864 & 0,3781 & 0,4067 & 0,3733 & 0,3409 \\
\hline 2011 & 0,2019 & 0,2985 & 0,3419 & 0,3044 & 0,4051 & 03 & 0,3792 & 0,4093 & 0,3778 & 0,3402 \\
\hline 2012 & 0,1872 & 0,2937 & 0,3563 & \begin{tabular}{|c|}
0,2969 \\
\end{tabular} & 0,4046 & 0,5745 & 0,3797 & 0,4102 & 0,3844 & 0,3442 \\
\hline 2013 & 0,1869 & 0,2903 & 0,3681 & 0,2967 & 0,4045 & 0,5851 & 0,3811 & 0,415 & 0,3845 & 0,3446 \\
\hline \multicolumn{11}{|c|}{ Parametry liniowej funkcji trendu $(y=a x+b)$} \\
\hline a & $-0,005$ & $-0,0076$ & $-0,0043$ & $-0,0034$ & $-0,0019$ & $-0,0036$ & $-0,003$ & $-0,0045$ & $-0,0014$ & $-0,0014$ \\
\hline $\mathrm{b}$ & 0,2382 & 0,3575 & 0,3772 & 0,3225 & 0,4139 & 0,6 & 0,4028 & 0,4465 & 0,3876 & 0,3497 \\
\hline $\mathrm{R}^{2}$ & 0,6334 & 0,9082 & 0,1803 & 0,4262 & 0,184 & 0,4388 & 0,5672 & 0,713 & 0,1295 & 0,1072 \\
\hline $\mathrm{F}^{* *}$ & 13,8 & 79,1 & 1,8 & 5,9 & 1,8 & 6,3 & 10,5 & 19,9 & 1,2 & 1,0 \\
\hline \multicolumn{11}{|c|}{ Parametry wielomianowej funkcji trendu $\left(y=a x^{2}+b x+c\right)$} \\
\hline $\mathrm{a}$ & 0,0002 & 0,0008 & 0,0032 & 0,0013 & 0,0013 & 0,0003 & 0,0009 & 0,0011 & 0,0013 & 0,0014 \\
\hline $\mathrm{b}$ & $-0,0076$ & $-0,0166$ & -399 & $-0,0172$ & $-0,0164$ & $-0,0067$ & $-0,0133$ & $-0,0162$ & $-0,0156$ & $-0,0163$ \\
\hline c & 0,2434 & 0,3755 & 0,4485 & 0,3501 & \begin{tabular}{l|}
0,4429 \\
\end{tabular} & 0,6149 & 0,4233 & 0,47 & 0,416 & 0,3795 \\
\hline $\mathrm{R}^{2}$ & 0,6423 & 0,9761 & 0,8442 & 0,8021 & \begin{tabular}{c|}
0,7336 \\
\end{tabular} & 0,455 & 0,9106 & 0,9687 & 0,8412 & 0,7517 \\
\hline
\end{tabular}

* Wykorzystanie wielomianu kwadratowego jako funkcji trendu wynikało z parabolicznego kształtowania się zmian wytwarzania w efekcie oddziaływania zjawisk kryzysowych (por. rysunek 2.).

** Wartości statystyki F pozwoliły na ocenę liniowości funkcji (kursywą zaznaczono statystyki nieistotne dla $\alpha=0,05)$.

A: Rolnictwo, leśnictwo, rybołówstwo; B-E: Przemysł; F: Budownictwo; G-I: Handel, transport, zakwaterowanie i gastronomia; J: Informacja i komunikacja; K: Finanse i ubezpieczenia; L: Obsługa nieruchomości; M-N: Usługi profesjonalne, naukowe i techniczne, administracyjne i wspierające; O-Q: Administracja publiczna, obrona narodowa, edukacja, ochrona zdrowia i opieka społeczna; R-U: Sztuka, rozrywka, rekreacja, usługi pozostałe, działalność gospodarstw domowych oraz organizacji międzynarodowych.

Źródło: opracowanie własne na podstawie danych Eurostat: [Eurostat, National..., (data wejścia: 23.07.2015); Eurostat, Population..., (data wejścia: 23.07.2015)].

W 2004 roku, a zatem w roku znacznego rozszerzenia Unii Europejskiej, największe dysproporcje występowały w sferze finansów. Znaczną skalę nierówności odnotowano także w usługach profesjonalnych, informacyjnych i obsłudze nieruchomości, a więc w branżach często uznawanych za wyznaczniki rozwoju nowoczesnej gospodarki opartej na wiedzy. Najmniejsze zróżnicowania miały miejsce w rolnictwie, handlu oraz przemyśle i w tych branżach były wyraźnie niższe niż dla gospodarek ogółem. W związku 
z tym, można uznać, że u progu pogłębionych zjawisk integracyjnych największe nierównomierności dotyczyły branż będących jednostkami motorycznymi rozwoju, a najmniejsze dysparytety tych o tradycyjnym charakterze.

Najgłębsze międzynarodowe dysproporcje wartości dodanej brutto na mieszkańca utrzymały się w sferze finansów również w 2013 roku. Po 10 latach integracji europejskiej pojawiły się podobnie głębokie dysparytety w usługach profesjonalnych i informacyjnych. Świadczy to o trwałości relacji międzybranżowego zróżnicowania poziomu zaawansowania poszczególnych gospodarek narodowych. Równocześnie fakt ten potwierdza pozycja rolnictwa, przemysłu i handlu jako branży o najbardziej równomiernym rozkładzie wartości dodanej brutto na mieszkańca między państwami członkowskimi Unii Europejskiej także w 2013 roku. Wobec tego, można wnioskować, że o dysproporcjach wytwarzania decyduja głównie dynamicznie rozwijające się, współczesne branże wiedzochłonne, w znacznych stopniu opierające się na pracy wykwalifikowanego personelu, które przesądzają o konkurencyjności poszczególnych państw.

\section{Dynamika rozwoju branż a ich międzynarodowe zróżnicowanie}

Weryfikacja hipotezy o występowaniu największych dysparytetów w ramach sektorowych biegunów wzrostu wymaga określenia charakteru poszczególnych agregatów branżowych. Celem identyfikacji tzw. jednostek motorycznych czy też sektorowych biegunów wzrostu dokonano oceny rzeczywistego tempa rozwoju poszczególnych agregatów branżowych w Unii Europejskiej, określanego przez skalę zmian wartości dodanej brutto w cenach bieżących na mieszkańca, w latach 2004-2013. Tak oszacowana dynamika rozwoju odzwierciedla nie tylko wzrost skali funkcjonowania danej branży oraz wzrost jej produktywności, ale i zmiany relacji cenowych wynikające $z$ gry popytu i podaży, a determinujące procesy rozwojowe. Oszacowanie procentowej zmiany wartości dodanej brutto na mieszkańca pozwoliło zakwalifikować badane agregaty branżowe do czterech grup o odmiennym tempie wzrostu. Branże o wyższej niż przeciętna dynamice rozwoju zostały włączone do 4. lub 3. grupy klasyfikacyjnej, a rozwijające się relatywnie najwolniej do 1. lub 2. Przedziały klasyfikacyjne zbudowano na podstawie progów wyznaczonych przez relacje średniej $+/$ - odchylenie standardowe skali przyrostu produkcji (przyjęły one poziomy: $13,0 \% ; 27,2 \%$ i $41,5 \%$ ) oraz alternatywnie przez relacje mediany $+/$ - odchylenie ćwiartkowe (przyjęły one poziomy: 14,4\%; 29,3\% i 40,0\%). Wyniki tych specyfikacji zestawiono w tabeli 2.

Zdecydowanie najszybszą dynamiką przyrostu wyróżniała się działalność z zakresu usług: profesjonalnych, naukowych i technicznych oraz administracyjnych i wspierających. Ta grupa, tzw. usług biznesowych, jako jedyna w obu wersjach klasyfikacyjnych została włączona do 4. grupy klasyfikacyjnej, a wytwarzana w niej wartość dodana w analizowanym okresie wzrosła niemal o połowę. Usługi biznesowe można uznać więc za współczesny sektor wiodący.

Za jednostki motoryczne rozwoju również można uznać: usługi rekreacyjno-kulturowe i pozostałe oraz finansowe i ubezpieczeniowe (w zależności od wersji klasyfikacji 
grupy: 4. lub 3.), a jednocześnie obsługi nieruchomości i usługi publiczne - administrację publiczna, edukację, ochronę zdrowia (grupa 3. w obu wersjach klasyfikacyjnych).

TABELA 2.

Procentowy przyrost wartości dodanej brutto per capita w cenach bieżących, w latach 2004-2013, w UE-28 oraz klasyfikacja branż według dynamiki rozwoju (1. - grupa o najniższej dynamice rozwoju, 4. - grupa o najwyższej dynamice rozwoju)

\begin{tabular}{|l|r|r|r|r|r|r|r|r|r|r|r|}
\hline & A & B-E & F & G-I & J & K & L & M-N & O-Q & R-U & A-U \\
\hline $\begin{array}{l}\text { Przyrost wartości dodanej } \\
\text { brutto per capita } \text { w latach } \\
\text { 2004-2013 (w \%) }\end{array}$ & 5,7 & 14,4 & 5,2 & 23,3 & 25,6 & 40,0 & 36,3 & 47,7 & 33,0 & 41,2 & 26,7 \\
\hline $\begin{array}{l}\text { Grupa klasyfikacyjna } \\
\text { w ujęciu średnia +/- od- } \\
\text { chylenie standardowe }\end{array}$ & 1 & 2 & 1 & 2 & 2 & 3 & 3 & 4 & 3 & 3 & $\mathbf{x}$ \\
\hline $\begin{array}{l}\text { Grupa klasyfikacyjna } \\
\text { w ujęciu mediana +/- od- } \\
\text { chylenie ćwiartkowe }\end{array}$ & 1 & 2 & 1 & 2 & 2 & 4 & 3 & 4 & 3 & 4 & $\mathrm{x}$ \\
\hline
\end{tabular}

A: Rolnictwo, leśnictwo, rybołówstwo; B-E: Przemysł; F: Budownictwo; G-I: Handel, transport, zakwaterowanie i gastronomia; J: Informacja i komunikacja; K: Finanse i ubezpieczenia; L: Obsługa nieruchomości; M-N: Usługi profesjonalne, naukowe i techniczne, administracyjne i wspierające; O-Q: Administracja publiczna, obrona narodowa, edukacja, ochrona zdrowia i opieka społeczna; R-U: Sztuka, rozrywka, rekreacja, usługi pozostałe, działalność gospodarstw domowych oraz organizacji międzynarodowych.

Źródło: opracowanie własne na podstawie danych Eurostat: [Eurostat, National..., (data wejścia: 23.07.2015); Eurostat, Population..., (data wejścia: 23.07.2015)].

Najmniejszą dynamiką przyrostu wytwarzania odznaczyło się budownictwo i rolnictwo, które zaliczono do grupy 1. Natomiast do grupy 2. włączono: przemysł, handel, transport, zakwaterowanie i gastronomię, a także usługi informacyjno-komunikacyjne, które odnotowały nieznacznie niższy przyrost wartości dodanej niż ogółem dla gospodarki. Branże te w najmniejszym stopniu odpowiadały za dynamikę rozwoju.

Zestawiając charakterystykę branżową określoną przez przyrost wartości dodanej brutto oraz skalę nierówności międzynarodowych, można wnioskować, że to przede wszystkim jednostki motoryczne odpowiadają za zróżnicowania przestrzenne w Unii Europejskiej, choć relacje te nie są jednoznaczne. Współczynnik korelacji między średnim współczynnikiem Giniego w latach 2004-2013 dla poszczególnych branż a procentowym przyrostem wytwarzania w latach 2004-2013 wyniósł 0,63. Wyższa dynamika wzrostu łączy się więc z większymi dysproporcjami międzynarodowymi. Generująca największe nierówności branża finansowo-ubezpieczeniowa została określona jako jednostka motoryczna i włączona do 4. lub 3. grupy. Odpowiadająca za znaczne zróżnicowania branża usług biznesowych rozwijała się najbardziej dynamicznie. Niemniej już branża usług informacyjno-komunikacyjnych, wykazująca duże nierówności w układzie międzynarodowym, cechowała się tempem wzrostu poniżej średniej dla gospodarki ogółem, choć często jest uznawana za wyznacznik rozwoju nowoczesnego modelu gospodarki opartej na wiedzy. 


\section{Podsumowanie}

Warto zauważyć, że przeprowadzone badania wskazują na występowanie znacznych dysproporcji wytwórczych w UE-28. Ich wymownym odzwierciedleniem jest zestawienie w rankingu krańcowych wartości dodanych brutto per capita państw, a mianowicie: wyniki Bułgarii osiagnęły poziom zaledwie 6\% wartości dla Luksemburga. Dalsza integracja wewnątrzunijna wymaga koncentracji uwagi na zmniejszeniu tych dysproporcji.

Ogólna ocena dotychczasowych efektów procesów konwergencji w Unii Europejskiej jest pozytywna. Dysproporcje wytwórcze uległy zmniejszeniu między 2004 a 2013 rokiem. Jednak obserwowane od 2008 roku zjawiska kryzysowe są źródłem szeregu wyzwań, również w wymiarze osiagania zbieżności poziomu wytwarzania. Tendencje konwergencyjne uległy bowiem wyraźnemu załamaniu wraz z ujawnieniem się problemów koniunkturalno-systemowych. Kryzys potęgował międzynarodowe zróżnicowanie wytwarzania zarówno w ujęciu ogółem, jak i w większości branży. Przeprowadzona analiza dysproporcji wewnątrzunijnych sugeruje, że minimalizacja nierówności wytwórczych przyjmuje charakter procykliczny. Zwraca uwagę fakt, że napięcia pojawiające się w okresie załamania wywołują relatywnie największe koszty w państwach konwergujących, wyhamowując procesy osiagania spójności gospodarczej. Tym samym wyrównywanie poziomu rozwojowego jest warunkowane wysiłkami ukierunkowanymi w stronę zapewnienia trwałego wzrostu gospodarczego. Obserwacja ta podkreśla także konieczność wypracowania mechanizmów wspierających osiaganie zbieżności nawet w sytuacji dekoniunktury, a więc przesunięcia ciężaru absorpcji negatywnych szoków na gospodarki wyżej rozwinięte.

Przeprowadzone analizy dowodzą trwałości relacji międzybranżowych w zakresie skali zróżnicowania pomiędzy poszczególnymi gospodarkami Unii Europejskiej. Dokonana identyfikacja branży o największych dysproporcjach wytwórczych pozwala wyróżnić: finanse, usługi profesjonalne i informacyjne. Były to branże o największych dysparytetach tak w poczattkowym, jak i ostatnim roku analizy. Natomiast do branż o najmniejszych różnicach należały: rolnictwo, przemysł i usługi tradycyjne (handel, transport, zakwaterowanie i gastronomia).

Należy zaznaczyć, że o dysproporcjach wytwarzania w Unii Europejskiej przesądzaja głównie dynamicznie rozwijające się, współczesne branże wiedzochłonne, które przyjmuja charakter jednostek motorycznych, koncentrując innowacje i odznaczając się najwyższą dynamiką wartości dodanej brutto per capita. Wewnątrzwspólnotowe procesy rozwoju mają więc kształt polaryzacyjno-dyfuzyjny. Zaawansowanie branż o cechach biegunów wzrostu w poszczególnych gospodarkach pozostaje zróżnicowane w związku z odmiennymi możliwościami kreacji i absorpcji nowoczesnych rozwiązań. W efekcie stanowi ono czynnik ograniczający wyrównywanie się poziomu rozwoju państw członkowskich Unii Europejskiej. Wobec czego, konieczne staje się zwiększanie potencjału endogenicznego gospodarek konwergujących, który umożliwi im skuteczniejszą dyfuzję nowoczesnych rozwiązań. 


\section{Literatura}

Foster J., Seth S., Lokshin M., Sajaia Z., 2013, A Unified Approach to Measuring Poverty and Inequality. Theory and Practice, The World Bank, Washington, DC, DOI: 10.1596/978-0-8213-8461-9.

In It Together: Why Less Inequality Benefits All, 2015, OECD Publishing, Paris, http://dx.doi.org/10.1787/9789264235120-en.

Jabkowski P., 2009, Miary nierówności spotecznych - podstany metodologiczne, [w:] Spór o spoteczne znaczenie spotecznych nierówności, K. Podemski (red.), Wydawnictwo Naukowe Uniwersytetu im. Adama Mickiewicza w Poznaniu, Seria Socjologia nr 65, Poznań.

Klodt H., 1995, Productivity Growth in Service and Non-Service Industries: Implications for Convergence, [in:] The Service Sector: Productivity and Growth, E. Felli, F. C. Rosati, G. Tria (eds.), Physica-Verlag, Rome, Italy.

Kołodko G.W., 2008, Wedrujacy świat, Wydawnictwo Prószyński i S-ka, Warszawa.

Kołodko G.W., 2014, Spoteczne i przestrzenne aspekty zróżnicowania dochodów we wspótczesnym śniecie, „Nierówności Społeczne a Wzrost Gospodarczy”, nr 39 (3/2014).

Kozak Z., 2001, Ekonomia zacofania i rozwoju, Monografie i opracowania, nr 477, Oficyna Wydawnicza Szkoły Głównej Handlowej, Warszawa.

National Accounts by 10 branches - aggregates at current prices [nama_nace10_c], Gross value added (at basic prices), Million euro, Eurostat, http://ec.europa.eu/eurostat/data/ database (data wejścia: 23.07.2015).

Piketty T., 2015, Ekonomia nierónności, Wydawnictwo Krytyki Politycznej, Warszawa.

Population on 1 January by age and sex [demo_tjan], Eurostat, http:/ / ec.europa.eu/eurostat/ data/database (data wejścia: 23.07.2015).

Sassi M., 2011, Convergence Across the EU Regions: Economic Composition and Structural Transformation, "International Advances in Economic Research", 02, 17(1), DOI 10.1007/s11294-010-9286-8.

von Stackelberg K., Hahne U., 1998, Teorie rozwoju regionalnego, [w:] Rozwój ekonomiczny regionów. Rynek pracy. Procesy migracyjne. Polska, Czechy, Niemcy, S. Golinowska (red.), Raport IPiSS, z. nr 16, Warszawa. 